INTERNATIONAL JOURNAL OF CURRENT RESEARCH IN CHEMISTRY AND PHARMACEUTICAL SCIENCES

(p-ISSN: 2348-5213: e-ISSN: 2348-5221)

Www.ijcrcps.com

DOI: $10.22192 /$ ijcrcps

Coden: IJCROO(USA)

Volume 8, Issue 6 - 2021

Review Article

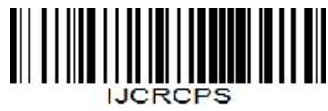

DOI: http://dx.doi.org/10.22192/ijcrcps.2021.08.06.003

\title{
Ecosystem cadastre of plant-soil interactions with nonferrous metals
}

\author{
Dr Chrysanthus Chukwuma Sr \\ Executive Director, The Chrysanthus Centre for Future-Oriented Studies \\ CTR Future-Oriented Ltd, Abakaliki, Ebonyi State, Nigeria \\ E-mail: cfos_nigeria@yahoo.com
}

\begin{abstract}
Especially in high concentrations, heavy metals are potential toxic substances in the environment with untoward impacts on fauna and flora. The metal toxicity is enhanced by chemical associations. The immediate and remote concerns for sustainable growth and development are the identification, control and management of factors which affect plants and soils with concomitant hunger, quality food deprivation, impairment of health in humans and animals. It becomes imperative to create opportunities for sustainable mechanisms or modalities to eradicate the sources of the issues and challenges in heavy metal or trace element poisoning in the ecosystem cadastre.
\end{abstract}

Keywords: mining operations, environmental monitoring, environmental variability, spatiotemporal variations, environmental management

\section{Introduction}

The major challenges, issues and opportunities facing the agriculturist, environmentalist, or ecologist for sustainable management of the ecosystem and to combat hunger (Chukwuma 2020a) are the identification of factors which may contribute to growth inhibition or retardation of the fauna and impairment of human and animal health (Chukwuma, 1994a; Chukwuma 1995a; Chukwuma 2011; Sethy and Ghosh, 2013; Chukwuma 2016) by mining and mining-related operations as well as other anthropogenic activities and natural occurrences; and to find

(C) 2021, IJCRCPS. All Rights Reserved remedies to resultant problems or issues (Chukwuma 2021). In polluting and derelict mine precincts including smelter sites, the waters become sterile due to the presence of toxic substances and infertile wastes. Certain of these toxic compounds are trace elements which are essential nutrients for higher plants, whereas at certain levels they may reach toxic concentrations. Disparate plant species accumulate several elements, particularly in mining areas via several mechanisms, such as competition and/or adaptive tolerance. Heavy metals constitute potential toxic substances and environmental problems; and present untoward 
impacts on agriculture (Jamil et al., 2014), quality of life and the human environment; and the metal toxicity is inextricably-linked to the chemical associations in soil (Sivapatham et al., 2014). Superimposed on these are the environmental and public health implications of low level $\mathrm{Pb}$ exposure in the paediatric population which may culminate in psychometric deficits (Chukwuma, 1997; Chukwuma, 2020b). Cadmium is a persistent and ubiquitous environmental pollutant that is associated with renal dysfunction and different disorders (Adams et al., 2011). Trace element prevalence in plants growing on diverse unpolluted soils depicts widespread variation in defined elements (Kabata-Pendias, 2000); and this is observable in contaminated and polluted sites. Information on toxicity and heavy metal levels in crops is also pertinent to identify adequate, subadequate, and marginal intake contents for human and/or animals, so that diseases associated with trace element deficiency can be prevented, controlled or managed.

\section{Issues, challenges and opportunities}

The monitoring, evaluation and assessment of the trend and spatial dissemination of both natural and anthropogenic sources of trace elements and heavy metals in our environment are crucial to obtain and maintain database of the proportion of chemical elements and compounds in soils and plants. Baseline data for the occurrence and distribution of heavy metals as contaminants and pollutants are important as criteria for assessment of critical heavy metal contents in agricultural soils. Varied studies of the sources, fluxes and pathways of elements in the surface environment has been the focus of both national and international research communities in response to pollution and health impacts. Rural and agricultural areas have been precincts of interest where there may be incidence and prevalence of the perturbation of heavy metals on ecological and farming systems. Appreciable number of inhabitants is in the urban areas where natural geochemical elemental processes and in-puts undergo singnificant modifications and variations or completely masked by contamination due to industrial activities and urban development. In several non-industrialised or low middle income countries with non-extant, non-compliant, unenforceable legislation or at its infancy, polluted or contaminated derelict mines or wastelands have been converted for agricultural purposes (Chukwuma, 1996).

Environmental toxicology is associated with heavy metals or trace elements, ecological and health impacts of environmental contaminants and pollutants as well as the factors related to weather and climatic conditions. Environmental modification, variation and geographical perspective are pertinent in toxic-element- related issues which interact on the food chain as evident in the Enyigba-Abakaliki lead and zinc mine precinct and several parts of the world (Chukwuma 1993a; Chukwuma, 1994a,b). This study tends to explicate or elucidate plant-soil interactions as inextricably-linked to the environment, agriculture and health.

Exploitation precinct are polluted by the mining operations and subjected the fauna and flora population to health and environmental risks via the food chain. Warm, dry climates and, to a certain magnitude, humid, hot climates induce upward translocation of trace elements in soil profiles (Kabata-Pendias and Pendias, 1992).

Despite the sampling period, metal levels in soils and plants are greater than background values (Bidar et al., 2009). In contradistinction to certain heavy metals which accumulate mostly in senescent leaves and leaf sheaths, Zn ostensibly has a uniform distribution in the entire plant.

The relative $\mathrm{Pb}$ uptake of rice seedlings was greatest in the $\mathrm{pH}$ range of 4.5-5.9, and least in the $\mathrm{pH}$ range 5-6.5 (Chukwuma, 1994c). $\mathrm{Pb}$ content of rice grain is, therefore, highly dependent on the soil $\mathrm{pH}$ and is the highest at mean $\mathrm{pH}$ 5.3-5.9. Rice grain uptake of $\mathrm{Cd}$ was highest in the $\mathrm{pH}$ range 5.4-5.9, and lowest in the $\mathrm{pH}$ range 4.5-6.5 (Chukwuma, 1994c). Cd content of rice grains is markedly dependent on the soil $\mathrm{pH}$ and is the maximum at $\mathrm{pH} 5.5$ (Bingham et 
al., 1980). Cd accumulates less in leaves than in lower parts; but was not evident in rice leaves to which 109Cd was introduced (Kitagishi and Yamane, 1981). There is a perspicuous retardation of $\mathrm{Pb}$ translocation from root to shoot, as merely a small quantity is translocated to the shoot.

Heavy metal levels in soils and plants in the transect of a copper-tungsten mine demonstrated the impact of erstwhile base metal mining on the surficial ambient. Metal levels in soils depreciated with distance farther from the mine, and was manoeuvred mainly by aquatic mobility and topography (Jung, 2008). As determined (Chukwuma 1993b), metal contents in leaves were higher than in grains. The factors associated with the bioavailability of metals include soil $\mathrm{pH}$, cation exchange capacity, organic matter content, soil texture and chemical interactions (Jung 2008).

Plants containing $\mathrm{Zn}$ at phytotoxic concentrations are not implicated in any toxicity in animals and humans because its adverse effect is attenuated in the food chain. $\mathrm{Zn}$ phytotoxicity may result at $\mathrm{pH}$ 6.5 or less. Due to the antagonistic relationship of $\mathrm{Cd}$ and $\mathrm{Zn}$, the $\mathrm{Cd} / \mathrm{Zn}$ ratio (0.002-0.004) in soils is ostensibly beneficial in the prevention or obliteration of toxic accumulation of $\mathrm{Cd}$ in food crops (Chukwuma 1993a; Chukwuma, 1994a,b).

Certain repercussions exist in the interaction of $\mathrm{Cd}$ with other metals, especially $\mathrm{Zn}$. Cd and $\mathrm{Zn}$ are in the same group and share similar chemical attributes. They both exhibit biochemical antagonism; and their ratios are critical in biochemical outcomes. This similarity grants the latitude for their usual occurrence together with $\mathrm{Zn}$ predominating or in abundance. The established $\mathrm{Cd}: \mathrm{Zn}$ ratio in most staple foods is circa 1:100 (National Academy of Science, 1977). Data from a derelict mine transect revealed that the $\mathrm{Cd}: \mathrm{Zn}$ ratios were $1: 100$ and 1.57 respectively, for cultivated (staple foods) and wild plant species (Chukwuma, 1993a). It is suggested that there is mitigation in the potential toxicity of $\mathrm{Cd}$ by $\mathrm{Zn}$ via simple mass action effect specifically for cultivars, while other superimposed tolerance or adaptive mechanisms are operative in the wild plants.

The presentation of toxic elements in the soilplant system correlates to their discrete states. Elemental toxicity as determined by plant uptake is associated with the outcome both in the liquid and solid states of the soil. Toxic elements have stronger adsorption at high $\mathrm{pH}$ with more significant effect in light textured soils. Indubitably, $\mathrm{pH}$ variations influence trace metal solubility, as they are inter alia also governed by reductive dissolution and organic acid production (Charlatchka and Cambier, 2000). In a mine transect, the mean soil $\mathrm{pH}$ was 6.01 , and light textured brown powdery soil had the highest $\mathrm{Zn}$ and Cd concentrations (Chukwuma, 1994b).

There was disparity of the energy binding of each element to the soil. It was easier for $\mathrm{Cu}$ and $\mathrm{Zn}$ to be extracted from soil solution than $\mathrm{Cd}$ and $\mathrm{Pb}$ (Huang et al., 1977). There were fluctuations of metal levels in plant parts in contrast to soils over time. Bioaccumulation and transfer factors ranges farther away reflect and depict higher soil load of chemical elements at the mine and its periphery. The findings were that Panicum maximum is the best indicator species for $\mathrm{Cd}$ and $\mathrm{Pb}$ for the investigated soils (Chukwuma, 1994c). The most appropriate indicator plant species for trace element levels for the investigated cultivated areas were grass $(\mathrm{Cu})$, yam leaves $(\mathrm{Cu}, \mathrm{Ni})$, rice leaves $(\mathrm{Mn})$, rice leaves and grains $(\mathrm{Ni})$ and cassava leaves $(\mathrm{Zn})$. The greatest range was described for $\mathrm{Mn}$ in yam leaves, and the least variation for $\mathrm{Ni}$ in rice leaves (Chukwuma, 1995b).

Imperata cylindrica accumulated $\mathrm{Pb}$ but excluded both $\mathrm{Zn}$ and $\mathrm{Cd}$. The Ageratum conyzoides was determined as either an accumulator or indicator depending on the chemical element or whether it was being classified as regards plant uptake or the plant/soil ratio system (Chukwuma, 1993b).Thiaspi calaminare, a variant of the mountain pansy, Violea lutea accumulated $>10 \%$, whereas Equisetum arvense took up 0.1 to $1 \% \mathrm{Zn}$, and other trace elements in Western Europe 
(Edington and Edington, 1977). The basil Becium homblei is associated with copper deposits in Africa(Edington and Edington, 1977). The grass, Eriachne mucronata is associated with lead uptake (Cannon, 1971) in Australia. In Poland, dandelion, orchard grass, plantain, and lichens are ostensibly the best indicator plants for Cd levels in soils (Kabata- Pendias and Dudka, 1990). To elucidate the food-chain linkage in the bioaccumulation of heavy metals, the goat weed, Ageratum conyzoides may serve as a better indicator of the distribution of $\mathrm{Zn}, \mathrm{Pb}$ and $\mathrm{Cd}$. Imperata cylindrica and Bryophyllum pinnatum may be tenable for biopurification purposes. Dioscorea bulbifera could be useful for biological locating of ores (Chukwuma, 1993b). The mungbean may impose as a nickel indicator, accumulator, or excluder (Ahmad et al., 2007).

The usage of plants for monitoring heavy metal pollution in the terrestrial environment must inculcate the complex, integrated impacts of pollutant and contaminant sources as well as soilplant variables. In order to be detectable in plants, it becomes critical that pollutant and contaminant sources markedly spike the plant available metal level in soils.The essential and non-essential heavy metals $\mathrm{Fe}, \mathrm{Ni}, \mathrm{Mn}, \mathrm{Zn}, \mathrm{Cu}, \mathrm{Cd}, \mathrm{Cr}$ ) and $\mathrm{Pb}$ analyzed in four selected medicinal plants, Capparis spinosa, Peganum harmala, Rhazya stricta, and Tamarix articulate (Shah et al., 2013) showed that these plants are widely consumed as traditional medicine for treatment of diverse ailments. The heavy metal concentrations in the plants was found to decrease in the order: $\mathrm{Fe}>\mathrm{Zn}$ $>\mathrm{Mn}>\mathrm{Cu}>\mathrm{Ni}>\mathrm{Cr}>\mathrm{Cd}>\mathrm{Pb}$. These medicinal plants accumulate these elements at varied levels. Monitoring such medicinal plants for heavy metal contents is immensely valuable to physicians, health planners, health care professionals, and policymakers for the protection of the public from their adverse toxicity impacts.

Microorganisms which are capable of resisting elevated concentrations of toxic heavy metals are effective agents of bioremediation regarding such contaminants and pollutants. Halophilic microorganisms are useful in bioremediation due to their efficient and effective removal of heavy metals (Sowmya et al., 2014) in soil contaminated with various levels of $\mathrm{Ni}$. The rates of germination and percentage significantly diminished in the plants (Jamil et al., 2014). The pigments of photosynthesis, chlorophyll a, chlorophyll $\mathrm{b}$, and carotenoids also when different $\mathrm{Ni}$ concentrations were applied to the soil. Total protein and organic nitrogen decreased at elevated $\mathrm{Ni}$ levels. Bacteria serve in competent phytoremediation of heavy metal deranged soil. Improvement in seed germination and biochemical attribute of plants following Ni stress were detected with the inoculation of Bacillus licheniformis NCCP-59 strain. This bacterial strain may protect plants from the debilitating impacts of $\mathrm{Ni}$, and useful for the phytoremediation of Ni contaminated soils.

The reclamation of nonferrous metal-polluted soil via phytoremediation requires an entirely permanent plant cover. Selection of the most appropriate plant species necessitates the investigation of chemical element effects on plants over the specified period, and assurance that the chemical elements remain stored in root systems and not transferred to the aerial aspects. It then becomes imperative to study the seasonal and annual variations of metal bioaccumulation, transfer, and phytotoxicity (Chukwuma, 1993a; Bidar et al., 2009). Investigations of the spatiotemporal variations of sediment quality containing selected heavy metals and total hydrocarbons (THC) with the application of multivariate statistical techniques, such as principal components, cluster and lineal discriminant analyses discerned the environmental interpretation of a limited dataset for the identification of environmental quality (Alvarez et al., 2014). It was determined that Zn, $\mathrm{Cu}, \mathrm{Pb}, \mathrm{V}, \mathrm{As}$ and THC significantly contributed to sediment quality variations during the sampling period. 


\section{Environmental variability and resource dynamics}

Soil constitutes an aspect of a vital environmental, ecological and agricultural resource that needs protection from further degradation. An optimum supply of healthy food (Chukwuma 2020a; Chukwuma 2021) is required for the everincreasing global population. Chemical elements can affect both the yield and composition of crops. Therefore, a determination of the elemental status of all cultivated lands has to be made for the identification of yield-limiting deficiencies of essential micronutrients and the corresponding contaminated and polluted soils. The extensive variability of soil composition is influenced by several factors, the most vital of which are climatic status and parent material. Research on the association between trace elements and soil constituents explicates their behaviour in soils and in plant uptake. The fate and pattern of mobilized chemical elements by dissolution of parent substances are dependent on the ionic speciation of the soil solution. Significant alterations in element concentrations in soil solutions result due to precipitation, evaporation, and plant transpiration. The trajectories of trace element distribution, translocation and accumulation vary expansively for any element, plant species, and growth season.

Environmental pollution data depicting environmental variability vary extensively and are susceptible to disparate uncertainties, such as inter alia distance, pollution sources, natural background variation, spatiotemporal pollution build-up or degradation. Environmental variability relates to the unique variation in pollution levels between population units. In essence, the levels, dynamics and significance of heavy metals in composted waste materials are critical from two potentially conflicting dimensions of environmental legislation as to: (a) explicate and define end-of-waste criteria and augment recycling of composted residuals on land and (b) protect and preserve soil quality as well as create a barrier to contamination and pollution (Chukwuma 1996; Smith, 2009).

(C) 2021, IJCRCPS. All Rights Reserved
The development of a monitoring programme for the sampling of the same plant species using standardized sampling and analytical methods for the maximization of the comparability of data is pertinent (Chukwuma, 1998). There are expansive highly metalliferous precincts with ponds, lakes, rivers, streams, and other aquatic resources (Chukwuma 2020c). with diverse fauna and flora which are vulnerable to extreme quantities of trace elements or heavy metals which may be inimical to the ambient, animal and human health. Most of these plants are ubiquitous, and could be sampled regularly with standardized sampling and analytical techniques to monitor the time-trend or spatiotemporal dissemination of chemical elements which are potential environmental, animal and human health hazards.

\section{Discussion}

Invariably, there is the overwhelming need for the simultaneous management of soil on the entire spectrum of essential and toxic elements. Crops and livestock usually become subjected to latent hunger or latent toxicities. Plant response to an element or nutrient may be suppressed when growth or development is inhibited by toxicity or deficiency of another element antagonistically or synergistically. Soils with low levels of contaminants need protection using stringent measures from superimposed contamination, that is, pollution. Soils polluted by heavy metals must either be cleaned or at the least, elemental removal conducted to meet minimal concentration requirements for human health, optimum growth for plant and soil micro- and macro-organisms. Observed elemental concentrations in a given soil which exceed normal values, may be indications of untoward in-puts by agricultural activities, emissions via the air, parent rocks, and transportation of accumulated pollutants to soils, waters and plants (Gupta, 1991: Chukwuma, 2014).

Although, it is not every ambient that has been adversely exposed and susceptible to heavy metal and trace element contamination, pollution and toxicity, there is pertinence for concern (Guan and Peart, 2006; Chukwuma, 2014). Pb levels were 
found to be substantially higher in tree leaves on roadsides than in a park. Heavy metal concentrations were lower in the roots than in leaves; thus suggesting that heavy metal pollution of trees was mainly due to air pollution (Guan and Peart, 2006).

it is pertinent to address environmental perturbations in all aspects. Mobilization of different chemical elements at toxic levels in the environment can accumulate in the food chain. There is need for continuous investigation on the effects of mobility of metals for the evaluation of pollutants and contaminants to be absorbed by the biota and transferred to groundwater. This will provide for a replicable method for the assessment of aquatic ecosystem health in adjacent plateau reservoirs (Wu et al., 2014) and mine precinct. also, bioaccessibility tests are valuable on contaminated and polluted soils to evaluate phytostabilization impacts on the exposition risks for fauna and flora (Chukwuma, 2014).

\section{Conclusion}

Trace elements and their compounds constitute vital components of the biotic environment, and a vast majority of them are essential for the health of the fauna and flora. However, essential chemical elements can accumulate to toxic concentrations in the environment via anthropogenic activities, such as non-ferrous metal mining operations. It is pertinent to monitor the concentrations of elements which are bioaccumulated in wild terrestrial plant species for monitoring purposes. Certain plants specifically take up select trace elements in metalcontaminated or polluted soils, and have been used to locate ores. Data acquisition and collation using well-defined monitoring programme regarding the spatiotemporal distribution of metal- contaminants in a particular plant species, particularly in ambients with similar plant and soil features.

\section{References}

Adams F (Ed) (1984). Crop response to lime in the southern United States. In: Soil Acidity and liming, 2nd ed. American Society of Agronomy, Madison, WI, pp 211-65.

Adams, SV, Newcomb PA, Shafer MM, Atkinson C, Bowles EAJ, Newton KM, Lampe JW (2011). Sources of Cadmium Exposure Among Healthy Premenopausal Women. Sci Total Environ, Vol. 409, No. 9, pp.1632-37.

Ahmad MSA, Hussain M, Saddiq R, Alvi AK (2007). Mungbean: a nickel indicator, accumulator or excluder? Bull Env Contam Toxicol, Vol. 78, No. 5, pp. 319-24.

Alvarez OQ, Tagle ME, Pascual JL, Marín MT, Clemente AC, Medina MO, Palau RR, Alfonso MS (2014). Evaluation of spatial and temporal variations in marine sediments quality using multivariate statistical techniques. Environ Monit Assess, July 12 [Epub ahead of print]

Bajpai AC, Calus I, Fairley JA (1992). Descriptive Statistical Techniques. In: Methods of Environmental Data Analysis. C.N Hewitt (Ed), p 1, Elsevier, Amsterdam/New York.

Bidar G, Garçon G, Pruvot C, Verdin A, Shirali P, Douay F (2009)Seasonal and annual variations of metal uptake, bioaccumulation, and toxicity in Trifolium repens and Lolium perenne growing in a heavy metalcontaminated field. Environ Sci Pollut Res Int, Vol. 16, Nov. 1, pp. 42-53

Bingham FT, Page AL, Strong JE (1980). Yield and cadmium content of rice grain in relation to addition rates of cadmium, copper, nickel, and zinc with sewage sludge and liming. Soil Sci., Vol.130, pp.32-38.

Bodek I, Lyman W, Reehl WF, Rosenblatt DH (Eds) (1988). Environmental Inorganic Chemistry. Pergamon Press, New York. 
Bouka K, Povi Lawson-Evi P, Eklu-Gadegbeku K, Aklikokou K, Gbeassor M (2013). Heavy Metals Concentration in Soil, Water, Manihot esculenta Tuber and Oreochromis niloticus Around Phosphates Exploitation Area in Togo. Research Journal of Environmental Toxicology, Vol. 7, pp. 1828.

Cannon HL (1971). The use of plant indicators in ground water surveys, geologic mapping, and mineral prospecting. Taxon, Vol. 20, pp. 227-56.

Cataldo DA, Garland TR, Wildung RE, Drucker $\mathrm{H}$ (1978). Cadmium distribution and chemical fate in soybean plants. Plant Physiol., Vol. 62, pp. 566-70.

Cataldo DA, Wildung RE (1978). Soil and plant factors influencing the accumulation of heavy metals by plants. Environ Health Perspect., Vol. 27, pp. 149-159.

Charlatchka R, Cambier P (2000). Influence of reducing conditions on solubility of trace metals in contaminated soils. Water, Air, and Soil Pollution, Vol. 118, pp. 143-167.

Chukwuma Sr, C (1994a). A comparative study of cadmium, lead, zinc, $\mathrm{pH}$, and bulk density from the Enyigba lead and zinc mine in two different seasons. Ecotoxicol Environ Safety, Vol. 31, pp. 246-249.

Chukwuma Sr, C (1993a). Comparison of the accumulation of cadmium, lead and zinc in cultivated and wild plant species in the derelict Enyigba lead-zinc mine. Toxicol Environ Chem, Vol. 38, pp. 167-73.

Chukwuma Sr, C (1993b). Cadmium, Lead and Zinc from Terrestrial Plants in the EnyigbaAbakaliki Lead and Zinc Mine: Search for a Monitoring Plant Species in Trace Element Distribution. Bull. Environ. Contam. Toxicol., Vol. 51, pp. 665-71.

Chukwuma Sr, C (1994b). Contamination of soils and rice by heavy metals in the EnyigbaAbakaliki lead and zinc mine, Nigeria. Toxicol Environ Chem, Vol. 41, pp. 125-30.
Chukwuma Sr, C (1994c). Evaluating baseline data for lead $(\mathrm{Pb})$ and cadmium $(\mathrm{Cd})$ in rice, yam, cassava and guinea grass from cultivated soils in Nigeria. Toxicol Environ Chem., Vol 45, pp. 45-56.

Chukwuma Sr, C (1995a). Integrative Procedure for Environmental Impact Assessment, Planning and Management of Non-Ferrous Metal Mining Operations in Nigeria. Doctorate Academic Dissertation, Dept of Limnology and Environmental Protection, Faculty of Agriculture and Forestry, University of Helsinki, Finland, pp 47. DOI:10.3140/RG.2.2.34020.12167.

Chukwuma Sr, C (2021) Book.pdf. https://www.researchgate.net/publication/34 8163959_Book_pdf.

Chukwuma Sr, C (1995b). Evaluating baseline data for copper, manganese, nickel and zinc in rice, yam, cassava and guinea grass from cultivated soils in Nigeria. Agric Ecosystems Environ, Vol. 53, pp. 47-61.

Chukwuma Sr, C (1996). Evaluating baseline data for trace elements, $\mathrm{pH}$, organic matter content, and bulk density in agricultural soils in Nigeria. Water, Air and Soil Pollution, Vol. 86, pp.13-34.

Chukwuma Sr, C (2011). Environmental impact assessment, land degradation, and remediation in Nigeria: current problems and implications for future global change in agricultural and mining areas. The Int $\mathbf{J}$ Sustainable Dev World Ecology, Vol.18, pp. 36-41.

Chukwuma, C Sr (1997). Environmental lead exposure in Africa. Ambio, Vol. 26, No. 6, pp. 399-403.

Chukwuma Sr, C (2016). Approaches to issues and concepts of heavy metals in biochemical and biosynthetic pathways. https://www.iiste.org/ Journals/index.php/JBAH/article/view/3001 2. 
Chukwuma Sr, C (1998). Development and implementation of environmental monitoring and information systems for water resources. Environmental Management and Health 9(4): 153-159. https://doi.org/10.1108/0956616981022890 8 .

Chukwuma Sr, C (2014). Concerns in the sustainable management of heavy metals in plants and soils. J. Agric. Soil Sci. 2(9): 143-152.

Chukwuma Sr, C (2018). Bioinformatics-base and determinants in the spatiotemporal variations of emerging and reemerging infectious diseases. Journal of Ancient Diseases \& Preventive Remedies 06(02). DOI: $10.4172 / 2329.8731 .1000182$.

Chukwuma Sr, C (2020b). Environmental and public health repercussions of the heavy metal lead $(\mathrm{Pb})$ in the pediatric population. Biomedical Journal of Scientific \& Technical Research 31(3): 24274-24277. DOI:10.26717/BJSTR.2020.31.005112.

Chukwuma Sr, C (2020a). Hunger in the COVID19 pandemic. iJARR 5(11): 20-23.

Chukwuma Sr, C (2020c). To what extent for improved water supply? Editorial. IJARBS 7(12): i-ii: dOI: 10.22192/ijarbs.

Davies BE, Jones LHP (1988). Micronutrients and toxic elements. In: Russell's Soil Conditions and Plant Growth. Alan Wild (Ed), Longman S7T, pp 780-815.

Edington JM, Edington MA (1977). Ecology and Environmental Planning. Chapman and Hall, London.

Farago MD, Cole MM (1988). In: H. Sigel and A. Sigel (Eds), Nickel and its Role in Biology. Metal Ions in Biological Systems. Marcell Deker, New York, Vol. 23, Chap. 3.

Gisbert C, Almela C, Vélez D, López-Moya JR, de Haro A, Serrano R, Montoro R, NavarroAviñó J (2008). Identification of as accumulation plant species growing on highly contaminated soils. Int $\mathbf{J}$ Phytoremediation, Vol. 10, No. 3, pp. 185196.
Grupe M, Kuntze H (1987). Zur Ni-Mobilitt einer geogen belasteten Braunerde. Mitt. Dtsch. Bodenkundl. Gessellsch., Vol. 55, pp. 333.

Guan DS, Peart MR (2006). Heavy metal concentrations in plants and soils at roadside locations and parks of urban Guangzhou. J Environ Sci (China), Vol. 18, No. 3, p.:495-502.

Gupta UC (1979). In: J.O. Nriagu (Ed), Copper in the Environment. Part I. Ecological Cycling. John Wiley, New York, pp 255-88.

Huang CP, Elliot HA, Ashmead RM (1977). Interfacial Reactions and the Fate of Trace Metals in Soil-Water Systems. J Water Pollut Contr Fed, Vol. 49, No. 5, pp. 74556.

Hutchinson TC (1981). Nickel. In: N.W. Lepp (Ed), Effect of Heavy Metal Pollution on Plants, Vol. I. Effects of Trace Elements on Plant Function. Applied Science Publishers, London, pp 171-212.

Islam AKMS, Edwards DG, Asher CJ (1980). pH optima for crop growth. Results of a flowing solution culture experiment with six species. Plant Soil, Vol. 54, pp.339-57.

Jamil M, Zeb S, Anees M, Roohi A, Ahmed I, ur Rehman S, Rha ES (2014). Role of Bacillus licheniformis in phytoremediation of nickel contaminated soil cultivated with rice. Int $\mathbf{J}$ Phytoremediation, Vol. 16, No. 6, pp.55471.

Jung MC (2008). Heavy metal concentrations in soils and factors influencing metal uptake by plants in the vicinity of a Korean $\mathrm{Cu}-\mathrm{W}$ mine. Sensors (Basel), Vol. 8, No. 4, pp:2413-23.

Kabata-Pendias A (2000). Trace elements in Soils and Plants. Third Edition, CRC Press

Kabata-Pendias A, Dudka S (1990). Evaluating baseline data for cadmium in soils and plants in Poland. In: Lieth H, Markert B (Eds) Element Concentration Cadasters in Ecosystems - Methods of Assessment and Evaluation. VCH Verlagsgesellschaft $\mathrm{mbH}$, D-6840 Weinheim (FRG), pp 265-280. 
Kabata-Pendias A, Pendias H (1992). Trace Elements in Plants and Soils. CRC Press.

Kitagishi K, Yamane I (Eds) (1981). Heavy Metal Pollution in Soils of Japan. pp 302. Japan Science Society Press, Tokyo.

Kukurenda H, Lipski R (1982). Solubility of manganese in different soils and its availability to plants. Pamiet. Pulawski, Vol.76, pp. 172 (In Polish).

Lieth H, Markert B (Eds) (1990). Element concentration cadasters in ecosystems. State of the art and plans for the further development of an international research program till 1990. Element Concentration Cadasters in Ecosystems, pp 3-14. VCH Verlagsgesellschaft, D-6940 Weinheim Workshop, March 13-15, 1989, Osnabrück, FRG.

Liu DJ, Robbins GS, Pomeranz Y (1974). Composition and utilization of milled barley products. Cereal Chem., Vol. 51, pp. 30915.

Macnicol RD, Beckett PHT (1985). Critical concentrations of potentially toxic elements. Plant Soil. Vol. 85, pp.107-29.

Metson AJ, Gibson EJ, Hunt JL, Saunders WMH (1979). Seasonal variations in chemical composition of pasture. N.Z.J. Agric. Res., Vol. 22, pp. 309.

Morrison RS, Brooks RR, Reeves RD (1980). Nickel uptake by Alyssum species. Plant Sci Lett., Vol. 17, pp. 31.

National Academy of Sciences (1977). Drinking Water and Health. Printing and Publishing Office. National Academy of Sciences, Washington, DC.

Olade MA (1987). Dispersion of cadmium, lead and zinc in soils and sediments of a humid tropical ecosystem in Nigeria. In: Hutchinson TC, Meema KM (Eds) Lead, Mercury, Cadmium and Arsenic in the Environment, Scope 31, pp 303-313.

Rascio N, Navari-Izzo F (2011). Heavy metal hyperaccumulating plants: how and why do they do it? And what makes them so interesting? Plant Sci, Vol. 180, No. 2, pp. 169-81.
Rendig VV, Taylor HM (1989). Principles of Soil-Plant Relationships. McGraw Hill, New York, pp. 194-195.

Scheffer K, Stach W, Vardakis F (1978/1979). Uber die Verteilung der Schwermattalen Eisen, Mangan, Kupfer und Zink in Sommergesternpflanzen. Landwirtsch. Forsch., Vol. , pp. :156; Vol 2, pp.326.

Sethy SK, Ghosh S (2013) (2013). Effects of heavy metals on germination of seeds. J Nat Sci Biol Med, Vol 4, No. 2, pp. 272-275.

Shah A, Niaz A, Ullah N, Rehman A, Akhlaq M, Zakir M, Khan MS (2013). Comparative Study of Heavy Metals in Soil and Selected Medicinal Plants. Journal of Chemistry; Vol 2013 (2013), Article ID 621265, 5 pages http://dx.doi.org/10.1155/2013/621265.

Sivapatham P, Lettimore JM, Alva AK, Jayaraman K, Harper LM (2014). Chemical fractionation of $\mathrm{Cu}, \mathrm{Zn}, \mathrm{Cd}, \mathrm{Cr}$ and $\mathrm{Pb}$ in sewage sludge amended soils at the end of 65-d sorghum sudan grass growth. J Environ Sci Health A Toxic Hazard Subst Environ, Vol. 49, No. 11, pp. 1304-15.

Smith SR (2009). A critical review of the bioavailability and impacts of heavy metals in municipal solid waste composts compared to sewage sludge. Environ Int, Vol 35, No. 1, pp. 142-56.

Sowmya M, Rejula MP, Rejith PG, Mohan M, Karuppiah M, Mohamed Hatha AA (2014). Heavy metal tolerant halophilic bacteria from Vembanad Lake as possible source for bioremediation of lead and cadmium. J Environ Biol, Vol. 35, No. 4, pp.655-60.

Street JJ, Lindsay WL, Sabey BR (1977). Solubility and plant uptake of cadmium in soils amended with cadmium and sewage sludge. J Environ Qual., Vol. 6, pp.72-77.

Street JJ, Sabey BR, Lindsay WL (1978). The influence of heavy metal additions on availability and uptake of cadmium, lead, related to soil properties and extractable lead. J Environ Qual., Vol. 6, pp. 120- 3.

Underwood EJ (1971). Trace Elements in Human and Animal Nutrition. 4th Edition, Academic Press, New York. 
Wu B, Wang G, Wu J, Fu Q, Liu C (2014). Sources of heavy metals in surface sediments and an ecological risk assessment from two adjacent plateau reservoirs. PLoS One 9(7):e102 101.

\begin{tabular}{|c|l|}
\hline \multicolumn{2}{|c|}{ Access this Article in Online } \\
\hline and & Website: \\
& www.ijcrcps.com \\
\hline Quick Response Code & \\
\hline DOI: $10.22192 /$ ijcrcps.2021.08.06.003 \\
\hline
\end{tabular}

How to cite this article:

Chrysanthus Chukwuma Sr. (2021). Ecosystem cadastre of plant-soil interactions with nonferrous metals. Int. J. Curr. Res. Chem. Pharm. Sci. 8(6): 17-26.

DOI: http://dx.doi.org/10.22192/ijcrcps.2021.08.06.003 